\title{
Comparison of behavioral activity in two apparatus for food-deprived mice
}

\author{
JAMES M. MURPHY and Z. MICHAEL NAGY \\ Bowling Green State University, Bowling Green, Ohio 43403
}

\begin{abstract}
Behavioral arousal induced by food deprivation is well documented for rats tested in activity wheels, but activity levels may vary considerably for other species and when testing is done in other types of apparatus. The present study compared behavioral activity of ad-lib and food-deprived mice, as few studies have examined the effects of food deprivation in this species. Separate groups were tested continuously in activity wheels or $2 \mathrm{~h}$ daily in shuttle cages. Deprivation increased behavioral activity in both apparatus. The daily 2 -h shuttle cage test proved to be a reliable and economical measure of deprivation-induced behavioral arousal in mice.
\end{abstract}

Food deprivation in the laboratory rat is often reported to produce marked and reliable increases in behavioral activity (Campbell, 1964; Campbell \& Misanin, 1969). However, there are considerable interspecies differences in deprivation-induced behavioral arousal and, although the mouse is a popular subject for behavioral and pharmacological research, relatively few studies have examined the effects of chronic food deprivation in this species (cf. Baumeister, Hawkins, \& Cromwell, 1964; Campbell, Smith, Misanin, \& Jaynes, 1966; Cornish \& Mrosovsky, 1965). Thus, one purpose of the present study was to assess the effects of food deprivation on behavioral arousal in mice.

A second purpose of this study was to test the reliability of behavioral arousal induced by food deprivation in two types of apparatus, as considerable differences have been reported depending upon the apparatus used (Baumeister et al., 1964; Campbell, 1964; Cornish \& Mrosovsky, 1965; Miezejeski, Lamon, Collier, \& Hamilton, 1976). The most consistent manifestation of deprivation-induced behavorial arousal occurs when rats are tested in activity wheels, whereas the arousal is often less pronounced for other types of apparatus. The present study compared activity wheels and photocell shuttle cages for ad-lib and food-deprived mice. Shuttle cage groups were tested for only $2 \mathrm{~h}$ daily. This procedure was employed to determine if it would provide an economical yet reliable measurement of food-deprivation-induced behavioral arousal and if it would be comparable to the more traditional continuous monitoring in activity wheels.

\section{METHOD}

\section{Subjects}

Sixty-two Swiss Webster mice (Mus musculus) were used.

James M. Murphy is now at the Institute of Psychiatric Research, Indiana University School of Medicine, Indianapolis, Indiana 46223. Z. Michael Nagy was supported by a grant from the National Institute of Child Health and Human Development (HD-09145). Reprints are available from either author.
All animals had been bred and raised in-house and were randomly selected from the 100- to 140-day-old stock. Only males were used, to avoid estrous cycle variations in activity levels (Finger, 1961). Prior to the start of the experiment, animals were housed in $30.4 \times 18 \times 12.8 \mathrm{~cm}$ polyethylene cages with three to five mice per cage. Food and water were provided ad lib. The colony room was maintained at $24 \pm 1^{\circ} \mathrm{C}$ and was on a 12 -h light-dark cycle beginning at $0800 \mathrm{~h}$.

\section{Apparatus}

Activity wheels (Wahmann Company, Model LC-34) were separated by opaque partitions and were housed in a walk-in environmental chamber (Forma Scientific Company) maintained at $24 \pm 1{ }^{\circ} \mathrm{C}$ and $50 \%$ relative humidity. A 12-h lightdark cycle in the chamber matched the colony room cycle. Each activity wheel revolution registered one activity count. Counts were continuously recorded for individual wheels, and totals were printed every $2 \mathrm{~h}$ on apparatus located outside the sound-attenuated chamber.

Shuttle cages were constructed of clear Plexiglas and measured $26.5 \times 7.7 \times 10.0 \mathrm{~cm}$. Grid floors were made from 1-mm-diam stainless steel rods extending parallel to the width of the cage and spaced $5 \mathrm{~mm}$ center to center. Photocells and red-filtered light sources were mounted $5 \mathrm{~cm}$ from each end of the cages. A mouse had to interrupt alternate photocell beams and traverse at least the $16.5-\mathrm{cm}$ distance between photocells for each activity count. Individual cages were enclosed in sound-attenuated chambers maintained at $24 \pm 1^{\circ} \mathrm{C}$. A $6-\mathrm{W}$ incandescent ceiling light illuminated each chamber.

\section{Procedure}

Thirty-two mice were housed individually in the activity wheels and adjacent living cages 1 day prior to the start of the experiment. Activity was recorded over 3 subsequent days while food was continuously available. At the end of the light cycle on the 3rd predeprivation day, the animals were matched for activity levels and body weights. Sixteen mice were then terminally deprived of food,

The 30 mice tested in shuttle cages were housed individually in separate living cages the day before testing began. Subsequent daily activity test sessions were $2 \mathrm{~h}$ long and occurred at the same time each day during the light cycle. Food and water were not available during the daily 2 -h sessions but were available in the home cages for all mice over the 3 predeprivation test days. Following the third predeprivation session, subjects were paired according to activity levels and body weights and were assigned to one of two groups. The 15 animals assigned as controls continued to have ad-lib food in the home cages, 
whereas the 15 experimental animals were terminally deprived of food.

All mice had access to water throughout the experiment. Body weights were recorded daily, and activity testing continued until the expiration of all deprived animals.

\section{RESULTS AND DISCUSSION}

The mean body weights and activity scores are depicted in Figure 1 as a function of apparatus, group, and days. The control and deprived groups were equated for predeprivation body weights, and analyses confirmed that there were no reliable predeprivation body weight differences between control and deprived groups tested in activity wheels $[\mathrm{F}(1,30)<1.00]$ or shuttle cages $[\mathrm{F}(1,28)<1.00]$.

In both types of apparatus, all food-deprived mice expired by the 6th postdeprivation day. Deprived animals housed and tested in the activity wheels began to expire between Day 2 and Day 3 of deprivation. On postdeprivation Days 3, 4, and 5, respectively, there were 11,4 , and 3 surviving animals from the original group of 16 . Survival rates were somewhat longer for mice tested in the shuttle cages, as none of the deprived mice succumbed until after the 3rd day of food deprivation; nine animals survived through Day 4 and three animals through Day 5. Analyses of postdeprivation body weights for control and deprived groups on the days that all subjects survived indicated reliable Group by Day interactions for wheels $[\mathrm{F}(1,30)=133.94, \mathrm{p}<.0005]$ and shuttle cages $[F(2,56)=179.24, p<.0005]$, as well as significant main effects for group and day (ps $<.0005$ ). As can be seen in Figure 1, these findings are due to the rapid body weight loss of deprived compared to control groups. Although the time course of the deprivation effects was slightly different, it is evident that the general pattern of body weights over days was similar for groups tested in both apparatus.

Activity scores for pre- and postdeprivation days

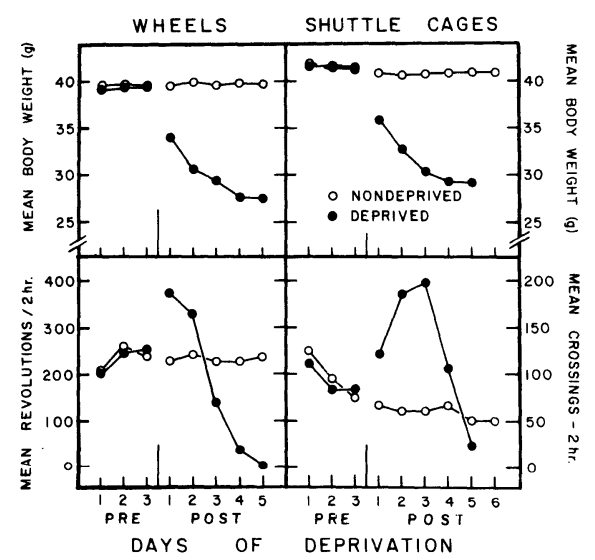

Figure 1. Mean body weights and activity scores as a function of apparatus and group during pre- and postdeprivation test days. were analyzed in the same manner as body weights. Predeprivation activity increased reliably over days for groups tested in the activity wheels $[\mathrm{F}(2,60)=6.47$, $\mathrm{p}<.005]$, suggesting that the mice became more proficient runners with continued experience. By contrast, predeprivation activity decreased over days for groups tested in shuttle cages $[\mathrm{F}(2,56)=8.79$, $\mathrm{p}<.0005$ ], suggesting an intersession habituation effect.

Figure 1 clearly shows that food deprivation increased behavioral activity as measured in both types of apparatus, whereas the activity of ad-lib controls remained relatively constant over days. Analysis of the activity wheel data for the 2 postdeprivation days on which all mice survived confirmed a reliable group effect $[F(1,30)=4.36, p<.05]$. All deprived mice tested in shuttle cages survived through 3 days of food deprivation and demonstrated a marked elevation of activity relative to controls on these test days $[F(1,28)=$ $17.06, \mathrm{p}<.0005]$. Following the initial increased activity in both apparatus over the first few days, the activity levels of surviving animals in the deprived groups began to drop precipitously with further deprivation. The decline is of greater magnitude and occurs at least a day earlier in wheels than in shuttle cages. This difference suggests that the continuous opportunity to run in activity wheels produces a more concentrated energy output and, therefore, a more rapid onset of inanition.

The results of the present investigation agree with the many studies that have reported behavioral arousal in food-deprived rats (Campbell, 1964; Campbell \& Misanin, 1969). On the other hand, a number of studies with rats have found that shuttle cage activity does not increase appreciably following food deprivation (cf. Baumeister et al., 1964; Cornish \& Mrosovsky, 1965; Miezejeski et al., 1976; Strong, 1957; Treichler $\&$ Hall, 1962). The discrepancy of the present findings with the previous studies may be due in part to a species or a procedural difference. It is clear, however, that food-deprived mice show substantial increases in behavioral activity under both conditions of the present study. Thus, the daily 2-h shuttle cage test employed here provides an economical assessment of deprivation-induced behavioral arousal and is comparable to continuous monitoring in activity wheels. Moreover, this $2-h$ procedure should allow for the easy introduction of pharmacological agents and physiological manipulations to explore the mechanisms underlying food-deprivation-induced behavioral arousal.

\section{REFERENCES}

Baumeister, A., Hawkins, W. F., \& Cromwell, R. L. Need states and activity level. Psychological Bulletin, 1964, 61, 438-453.

Campbell, B. A. Theory and research on the effects of water deprivation on random activity in the rat. In M. J. Wayner (Ed.), Thirst. New York: Pergamon Press, 1964. 
Campbell, B. A., \& Misanin, J. R. Basic drives. Annual Review of Psychology, 1969, 20, 57-84.

Campbell, B. A., Smith, N. F., Misanin, J. R., \& Jaynes, J. Species differences in activity during hunger and thirst. Journal of Comparative and Physiological Psychology, 1966, 61, 123-127.

Cornish, E. R., \& Mrosovsky, N. Activity during food deprivation and satiation of six species of rodent. Animal Behaviour, $1965,13,242-248$.

Finger, F. W. Estrous activity as a function of measuring device. Journal of Comparative and Physiological Psychology, 1961, 54, 524-526.
Miezejeski, C. M., Lamon, S., Collier, G., \& Hamilton, L. W. Partitioning of behavioral arousal. Physiology \& Behavior, 1976, 17, 581-586.

Strong, P. N., JR. Activity in the white rat as a function of apparatus and hunger. Journal of Comparative and Physiological Psychology, 1957, 50, 596-600.

Treichler, F. R., \& Hall, J. F. The relationship between deprivation weight loss and several measures of activity. Journal of Comparative and Physiological Psychology, 1962, 55, 346-349.

(Received for publication April 11, 1979.) 